\title{
Novel use of the wild species Cephalaria joppensis for silage preparation and its nutritive value for feeding lactating dairy cows
}

\author{
J. Miron, ${ }^{* 1}$ Z. G. Weinberg,† Y. Chen,† D. Miron, ${ }^{\star}$ Y. Raviv, $\ddagger$ A. Bloch,‡ E. Yosef, ${ }^{*}$ M. Nikbahat, ${ }^{*}$ A. Zenou, ${ }^{*}$ \\ M. Daklo,§ K. Nashef,§ and U. Kushnir§ \\ ${ }^{*}$ Department of Ruminant Sciences, Institute of Animal Sciences, and \\ †Forage Preservation Unit, Agricultural Research Organization (ARO), PO Box 6, Bet Dagan 50250, Israel \\ $\ddagger$ Massuot Yitzhak Feeding Center, Moshav Massuot Yitzhak, Sade-Gat 79858, Israel \\ $\S D e p a r t m e n t$ of Field Crops, Institute of Plant Sciences, Agricultural Research Organization (ARO), Bet Dagan 50250, Israel
}

\section{ABSTRACT}

This study presents a novel method for use of the wild plant species Cephalaria joppensis (CJ) as agricultural forage for ruminants. Domesticated CJ tends to have higher crop mass yield per hectare than a commercial wheat variety $(\mathrm{W})$ but is similar in in vitro dry matter (DM) digestibility. This study was composed of 3 experiments. Experiment 1 aimed to measure effects of ensiling CJ versus $\mathrm{W}$ in packed polyethylene-wrapped bales. Three types of ensiled bales were produced for each plant: 1) direct-cut CJ versus W packed solely; 2) direct-cut CJ versus $\mathrm{W}$ mixed as sole roughage source together with dietary ingredient and packed in bales to create CJ total mixed ration (CJ-TMR) or W-TMR; 3) CJ silage versus $\mathrm{W}$ silage mixed as one-third of dietary roughage source together with two-thirds sorghum (S) silage and additional dietary ingredients and packed in bales to create CJ-S-TMR or W-S-TMR. Data showed that packing and wrapping created anaerobic conditions within the 4 types of TMR bales while reducing $\mathrm{pH}$ (4.12 to 4.37). Dry matter loss during ensilage was higher for the 2 types of TMR containing W compared with CJ. Ensilage decreased soluble nitrate content as well as yeast and mold contamination, and the 4 types of TMR bales were characterized by a long outdoor shelf life $(3 \mathrm{mo})$ and high stability under aerobic exposure. Experiment 2 aimed to measure the intake and digestibility by sheep of the 4 types of packed TMR after $90 \mathrm{~d}$ of ensiling. Data demonstrated higher voluntary intake of the CJ-TMR compared with the other TMR types. The CJ-TMR was characterized by higher digestibility of DM, crude protein, and neutral detergent fiber components compared with the CJ-S-TMR. Experiment 3 examined intake, digestibility, and milk production by 21 pairs of lactating cows individually fed CJ-S-TMR versus W-S-TMR. Similar intake (21.6

Received October 25, 2011.

Accepted March 23, 2012.

${ }^{1}$ Corresponding author: jmiron@agri.gov.il to $22.0 \mathrm{~kg} / \mathrm{d}$ ) and digestibility of DM and crude protein were observed in cows fed the 2 TMR types (68 to $69 \%$ and 66 to $68 \%$, respectively). However, neutral detergent fiber and cellulose digestibility were slightly higher in the cows fed W-S-TMR and this was reflected in a small increase in their milk and energy-corrected milk yield ( 36.5 and $31.4 \mathrm{~kg} / \mathrm{cow}$ per day, respectively) compared with cows fed CJ-S-TMR (35.5 and $30.4 \mathrm{~kg} /$ cow per day, respectively). Results demonstrate that direct-cut CJ used as is, or CJ silage can be included and ensiled in TMR bales for feeding productive ruminants as a substitute for wheat silage.

Key words: Cephalaria joppensis, ensiled bale, lactating cow, intake and digestibility

\section{INTRODUCTION}

Feeding productive ruminants is the largest cost associated with milk and meat production, typically accounting for 60 to $70 \%$ of total production costs. Roughage is necessary to maintain a healthy rumen environment and prevent digestive problems and it is included in the TMR of lactating dairy cows at levels of 300 to $500 \mathrm{~g} / \mathrm{kg}$ of DM to supply 180 to $200 \mathrm{~g}$ of NDF/ $\mathrm{kg}$ of DM in the diet (NRC, 2001). Due to the shortage of irrigation water, the predominant roughage grown in Israel on winter rainfall alone is wheat (Triticum aestivum) silage or hay, whereas summer-irrigated corn (Zea mays var. indentata) and sorghum (Sorghum bicolor) account for about one-third of the silage in the lactating cow TMR. Although much research effort has been invested worldwide in developing new wheat cultivars with increased crop yield and high quality for silage production, the yield of wheat forage is still limited to a range of 10 to $14 \mathrm{t}$ of DM/ha (Duncan et al., 2011; Miron et al., 2010, 2011a; Zuckerman et al., 2011). Hay yield of cool-season legume forage, including vetch (Vicia sativa) and clover (Trifolium alexandrinum), is lower than that of wheat, producing about 6 to $8 \mathrm{t}$ of DM/ha in Israel (Shteinberg et al. 2003). Thus, a 
need exists for high-yielding cool-season forage that can replace wheat and legume forages and grow in multiseasonal rotation with wheat, corn, and sorghum.

Over the last $3 \mathrm{yr}$, the wild plant Cephalaria joppensis (CJ) was selected and domesticated to grow during the winter and spring for use as an agricultural forage crop for ruminants. Global distribution of CJ includes the Mediterranean woodlands and shrublands and other regions in Asia, South and North America, and Africa that have similar climate conditions to the Mediterranean region (Atlas of Israeli Flowers, 2010). Unfortunately, there is a lack of information in the literature on the use of CJ as domesticated forage for sheep or lactating cows. Preliminary observations indicate that CJ sown in December can grow without irrigation, and that a range of 350 to $600 \mathrm{~mm}$ of rain/yr is needed to produce crop yields of 16 to 24 t of $\mathrm{DM} /$ ha. The optimal harvesting stage for maximal forage yield with in vitro DM digestibility of $62 \%$ was observed at the beginning of the flowering stage (April-May) and the freshly harvested forage was directly ensiled without prewilting (Miron et al., 2010, 2011a).

Recently, Massuot Yitzhak Feeding Center in Moshav Massuot Yitzhak, Sade-Gat, Israel established a commercial process that is based on the production of dense bales of silage or TMR under high pressure, followed by packing and wrapping with 8 to 9 layers of polyethylene stretch film. This system, which creates anaerobic conditions suitable for ensilage within the packed bales (Weinberg et al., 2011), was used in the present study to measure ensiling effects on composition and digestibility of freshly cut CJ or wheat (W), and of packed TMR containing fresh or pre-ensiled $\mathrm{W}$ or CJ.

This study was composed of 3 experiments. Experiment 1 aimed to measure the effects of ensiling CJ versus $\mathrm{W}$ alone or in packed TMR bales on chemical composition, nutrient loss during ensiling, aerobic stability of the silage, and in vitro digestibility. Experiment 2 aimed to measure the intake and digestibility by sheep of 4 types of packed ensiled TMR containing CJ or W included as sole fresh roughage, or silages of CJ or W included in (1:2) combinations with sorghum (S) silage. Experiment 3 aimed to examine intake, digestibility, and milk production by lactating cows fed ensiled packed TMR containing either CJ silage or W silage combined with S silage as the source of roughage.

\section{MATERIALS AND METHODS}

\section{Experiment 1: Wheat and CJ Agronomics and Ensiling in Packed Bales}

The optimal agronomical growth conditions for CJ use as a forage crop were determined in a preliminary study (Miron et al., 2010). Seeds of CJ were sown (15 $\mathrm{kg} / \mathrm{ha}$ ) on December 1, 2009, in a 10-ha commercial field in Moshav Massuot Yitzhak, Israel (longitude: $35^{\circ} \mathrm{E}$, latitude: $32^{\circ} \mathrm{N}$ ). Preemergent treatment against weeds included linuron $(2,000 \mathrm{~mL} / \mathrm{ha}$; Machteshim, Ashkelon, Israel), pendimethalin (5,500 $\mathrm{mL} / \mathrm{ha}$; Machteshim), and alachlor + terbuthylazine (4,000 mL/ha; Machteshim). Postemergence treatment applied used pronamide $(2,000 \mathrm{~g} / \mathrm{ha}$; Machteshim). Wheat (Triticum aestivum cultivar Galil) was sown (70 kg/ha), on November 15 , 2009 , in a neighboring 10-ha field, without any herbicide treatment. Urea and ammonium sulfate $(150 \mathrm{~kg}$ of $\mathrm{N} / \mathrm{ha}$ ) were applied for fertilization. No irrigation was applied, and winter precipitation was $406 \mathrm{~mm}$. Commercial harvest (5-cm stubble height) occurred at the beginning of flowering (April 30, 2010) for CJ and at the soft-dough stage of grain maturation (March 30, 2010) for wheat. One day before commercial harvest, all CJ or W plants from 5 subplots $\left(10 \mathrm{~m}^{2}\right.$ each) from 5 random locations in the 10-ha field were harvested (5$\mathrm{cm}$ stubble height) and weighed for quantitative determination of wet forage yield. Subsamples (4-kg whole plants) from each plot were taken, some of them $(2 \mathrm{~kg})$ dried overnight $\left(105^{\circ} \mathrm{C}\right)$ in 2 replicates of 1-kg each for $\mathrm{DM}$ yield calculation, and the rest dried $\left(60^{\circ} \mathrm{C}\right.$ for $\left.48 \mathrm{~h}\right)$, ground to pass a $1-\mathrm{mm}$ screen, and used for chemical analyses and in vitro DM digestibility measurements of source plant (SP; Table 1). This yield measurement method provided 5 to $7 \%$ greater forage yield than the forage yield of the entire field measured by weighing the packed ensiling bales and hay bales harvested from each field. Similar comparisons assessing this yield measurement method were published previously (DePeters et al., 1989; Miron et al., 2011b; Zuckerman et al., 2011).

Total fresh CJ or W forage from half of each field ( 5 ha) was harvested and chopped to at least 2- to $3-\mathrm{cm}$ particle size using a John Deere combine harvester (9660 STS; John Deere, Moline, IL), loaded directly into tracks, and delivered to Massuot Yitzhak Feeding Center. Wheat and CJ fresh forage was baled $(\sim 700$ $\mathrm{kg} / \mathrm{bale}$ ) under high pressure and then packed and wrapped with 8 to 9 layers of polyethylene stretch film. Four types of bales were prepared immediately after harvest: 1) 12 silage bales containing fresh chopped CJ, 2) 12 silage bales containing fresh chopped W, 3) 6 packed bales containing $34 \%$ chopped fresh CJ (on a DM basis) as the sole roughage source mixed with TMR ingredients (CJ-TMR; Table 2), and 4) 6 packed bales containing $34 \%$ chopped fresh $\mathrm{W}$ (on DM basis) as the sole roughage source mixed with TMR ingredients (WTMR; Table 2).

The 24 bales containing just chopped CJ or W were weighed at the beginning and end of the 30-d ensiling period and sampled after opening ( $3 \mathrm{~kg}$ sampled from 
Table 1. Forage yield, chemical composition, and in vitro DM digestibility of Cephalaria joppensis (CJ) and wheat (W) source plants (SP) at harvest and after ensilage in polyethylene-wrapped bales

\begin{tabular}{lccc}
\hline & \multicolumn{2}{c}{ SP } & \\
\cline { 2 - 3 } Parameter & $\mathrm{W}$ & CJ & SEM \\
\hline Yield of SP (t of DM/ha) & 12.0 & 16.4 & 0.37 \\
DM content in SP (g/kg) & 370 & 369 & 2.3 \\
NDF in SP (g/kg of OM) & 577 & 546 & 3.20 \\
Hemicellulose in SP (g/kg of OM) & 231 & 106 & 4.60 \\
Cellulose in SP (g/kg of OM) & 288 & 370 & 4.50 \\
Lignin in SP (g/kg of OM) & 57.3 & 70.0 & 2.09 \\
Soluble nitrates in SP (g/kg of DM) & 2.20 & 1.20 & 0.05 \\
In vitro DM digestibility of SP (\%) & 64.0 & 62.0 & 1.01 \\
DM content in silage (g/kg) & 367 & 365 & 7.0 \\
DM loss during ensiling (\%) & 10.0 & 8.90 & 0.60 \\
pH in silage & 4.42 & 4.56 & 0.17 \\
Soluble nitrates in silage (g/kg of DM) & 1.25 & 0.47 & 0.06 \\
Yeasts in silage & $10^{2.3}$ & $10^{2.5}$ & 5.0 \\
Molds in silage & $10^{2}$ & 0 & 4.5 \\
NDF in silage (g/kg of OM) & 609 & 599 & 3.75 \\
NDF solubilization in silage (\%) & 5.0 & 0 & 0.26 \\
CP in silage (g/kg of DM) & 84.1 & 85.8 & 6.7 \\
In vitro DM digestibility of silage (\%) & 61.0 & 60.0 & 0.7 \\
\hline
\end{tabular}

the middle of 4 bales of each silage type) to measure $\mathrm{DM}$ content $\left(48 \mathrm{~h}\right.$ drying at $\left.60^{\circ} \mathrm{C}\right)$, chemical composition, and in vitro digestibility, and to calculate ensiling losses (Table 1). The CJ or W silages were then mixed with $\mathrm{S}$ silage (in a ratio of 1:2 on a DM basis) and with additional TMR ingredients to prepare 34 bales of CJS-TMR, and 34 bales of W-S-TMR (Table 2). Bales from each of the 4 types of packed ensiled TMR $(\mathrm{n}=$ 4; Table 2) were weighed at the beginning and end of the $90-\mathrm{d}$ ensiling period, sampled after opening $(3 \mathrm{~kg}$

Table 2. Ingredients of the 4 types of TMR containing Cephalaria joppensis (CJ) or wheat (W) ensiled in packed polyethylene-wrapped bales

\begin{tabular}{|c|c|c|c|c|}
\hline \multirow[b]{2}{*}{ Ingredient ( $\mathrm{g} / \mathrm{kg}$ of $\mathrm{DM})$} & \multicolumn{4}{|c|}{$\mathrm{TMR}^{1}$} \\
\hline & W-S-TMR & CJ-S-TMR & W-TMR & CJ-TMR \\
\hline Chopped CJ & - & - & - & 340 \\
\hline CJ silage & - & 114 & - & - \\
\hline Chopped wheat & - & - & 340 & \\
\hline Wheat silage & 114 & - & - & - \\
\hline Sorghum silage & 226 & 226 & - & - \\
\hline Corn grain & 137 & 137 & 137 & 137 \\
\hline Barley grain & 65.8 & 65.8 & 65.8 & 65.8 \\
\hline Wheat grain & 65.8 & 65.8 & 65.8 & 65.8 \\
\hline Sunflower meal & 52.7 & 52.7 & 52.7 & 52.7 \\
\hline Canola meal & 25.8 & 25.8 & 25.8 & 25.8 \\
\hline Corn gluten feed & 144 & 144 & 144 & 144 \\
\hline DDGS $^{2}$ & 96.5 & 96.5 & 96.5 & 96.5 \\
\hline Whole cotton seeds & 6.7 & 6.7 & 6.7 & 6.7 \\
\hline Molasses & 24.8 & 24.8 & 24.8 & 24.8 \\
\hline $\mathrm{NaHCO}_{3}$ & 7.0 & 7.0 & 7.0 & 7.0 \\
\hline Ca-LCFA ${ }^{3}$ & 15.3 & 15.3 & 15.3 & 15.3 \\
\hline $\mathrm{NaCl}+\mathrm{CaCl}_{2}$ & 12.4 & 12.4 & 12.4 & 12.4 \\
\hline $\mathrm{CaCO}_{3}$ & 2.2 & 2.2 & 2.2 & 2.2 \\
\hline Urea & 3.0 & 3.0 & 3.0 & 3.0 \\
\hline Mineral + vitamin $\operatorname{mix}^{4}$ & 1.0 & 1.0 & 1.0 & 1.0 \\
\hline
\end{tabular}

${ }^{1} \mathrm{~W}-\mathrm{S}-\mathrm{TMR}=\mathrm{W}$ silage + sorghum $(\mathrm{S})$ silage $(1: 2$ on a DM basis) as the roughage source: CJ-S-TMR $=$ CJ silage $+\mathrm{S}$ silage (1:2 on a DM basis) as the roughage source; W-TMR $=340 \mathrm{~g}$ of fresh $\mathrm{W} \mathrm{DM} / \mathrm{kg}$ of DM; CJ$\mathrm{TMR}=340 \mathrm{~g}$ of fresh CJ DM $/ \mathrm{kg}$ of DM as the roughage source.

${ }^{2}$ Dried distillers grains with solubles.

${ }^{3}$ Calcium salts of long-chain FA.

${ }^{4}$ Containing (g/kg of mix DM): Zn, 24; Fe, 24; Cu, 12.8; Mn, 24; I, 1.44; Co, 0.32; Se, 0.32; 16,000,000 IU of vitamin $\mathrm{A} ; 3,200,000 \mathrm{IU}$ of vitamin $\mathrm{D}_{3}$; and 48,000 IU of vitamin $\mathrm{E}$. 
Table 3. Chemical composition, in vitro DM digestibility, DM losses, yeast and mold contamination, and aerobic stability of 4 types of packed TMR bales

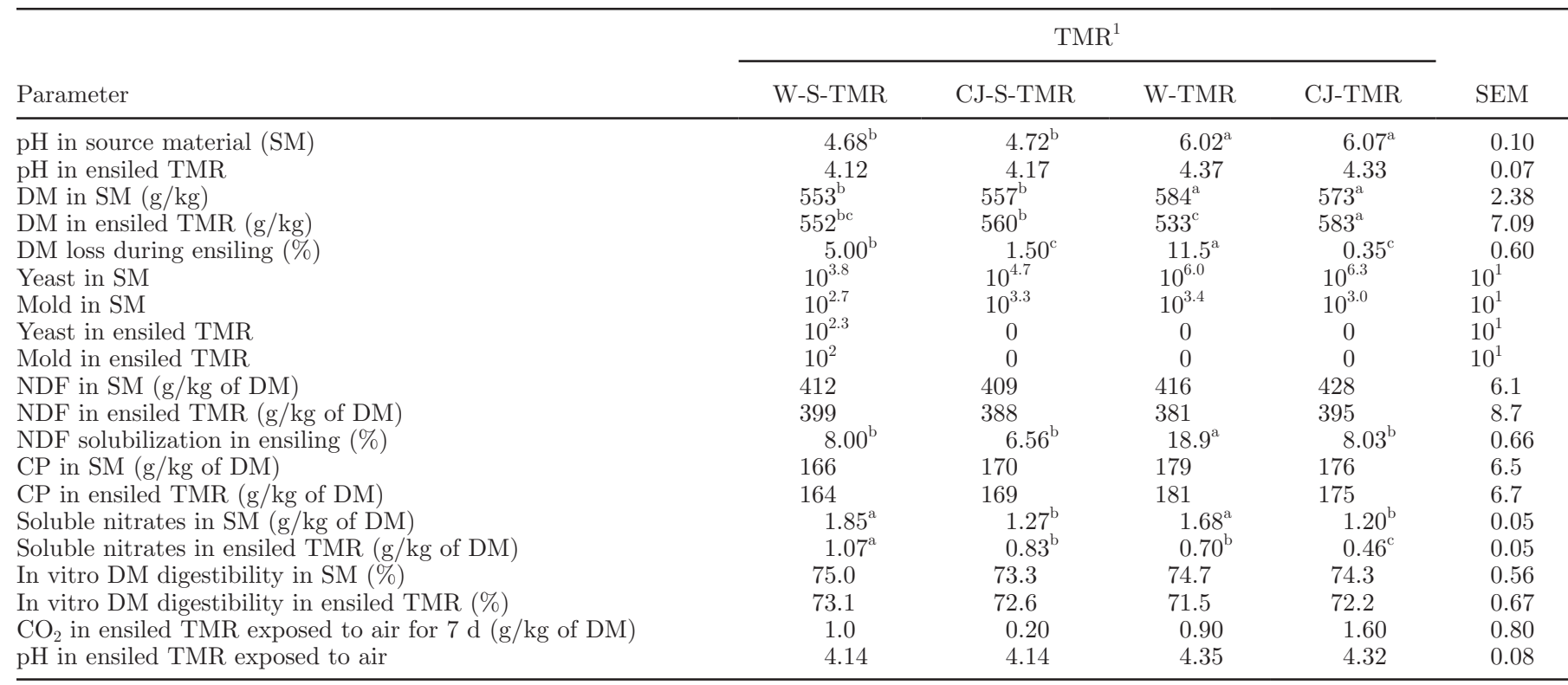

${ }^{a-c}$ Mean values within the same row followed by different superscripts differ at $P<0.05$.

${ }^{1} \mathrm{~W}-\mathrm{S}-\mathrm{TMR}=$ wheat $(\mathrm{W})$ silage $+\operatorname{sorghum}(\mathrm{S})$ silage $(1: 2$ on a DM basis $)$ as the roughage source; CJ-S-TMR = Cephalaria joppensis $(\mathrm{CJ})$ silage $+\mathrm{S}$ silage (1:2 on a DM basis) as the roughage source; W-TMR $=340 \mathrm{~g}$ of fresh $\mathrm{W}$ DM/kg of DM; CJ-TMR $=340 \mathrm{~g}$ of fresh CJ DM/ $\mathrm{kg}$ of DM as the roughage source.

from the center of each bale) to measure DM content (48 h of drying at $60^{\circ} \mathrm{C}$ ), chemical composition, and in vitro digestibility, and to calculate ensiling losses. Fresh samples taken from each TMR bale $(\mathrm{n}=4)$ were brought to the laboratory for analyses of aerobic stability of the ensiled TMR after $7 \mathrm{~d}$ exposure to air, as described by Weinberg et al. (2011). The rest of the ensiled bales of CJ-S-TMR $(\mathrm{n}=30)$ and W-S-TMR (n $=30$ ) were kept outdoors for an additional week and then delivered to the Bet Dagan dairy farm and used for the performance study with lactating cows.

\section{Experiment 2: Sheep Digestibility Trial}

From each of the 4 types of ensiled packed TMR bales (Tables 2 and 3), 2 bales of about $700 \mathrm{~kg}$ each, kept outdoors for $97 \mathrm{~d}$, were delivered to the Agricultural Research Organization (ARO) sheep house in Bet Dagan (Israel), which has 24 metabolic cages. These TMR bales were opened, mixed, and fed to male Assaf sheep $(\mathrm{n}=6 ; 1 \mathrm{yr}$ old, $45 \pm 1.5 \mathrm{~kg}$ of BW). Each of the 6 sheep (replicates), fed one of the TMR being tested for ad libitum intake (5\% orts), was held in an individual metabolic cage with free access to food and water. Total orts and feces excreted were collected daily from each sheep during $10 \mathrm{~d}$ of the digestion trial after $20 \mathrm{~d}$ of adaptation to the TMR. Feeds, orts, and feces samples were kept at $-20^{\circ} \mathrm{C}$ until composited per sheep and analyzed. Measurements included voluntary intake and digestibility of dietary DM, NDF, and protein by each individual sheep as described previously by Miron et al. (2011b). This sheep digestibility trial was carried out according to the guidelines, and under the supervision of the ARO Animal Care Committee.

\section{Experiment 3: Cow Digestibility and Performance Trial}

Ensiled packed bales of CJ-S-TMR $(\mathrm{n}=30)$ and WS-TMR ( $\mathrm{n}=30$; Tables 2 and 3 ) were delivered to the ARO dairy barn feed center in Bet Dagan. The 2 types of TMR bales were opened on a daily basis and fed ad libitum as the sole feed to 2 groups of 21 lactating cows each in the individual feeding dairy barn in Bet Dagan. The 2 groups of cows similar in lactation number (3.3) were blocked by DIM (60 to 120 vs. 120 to 180 ) and daily milk production ( 30 to 36 vs. 36 to $42 \mathrm{~kg} / \mathrm{cow}$ ) and randomly assigned within block to pairs fed the 2 dietary treatments for $2 \mathrm{wk}$ of adaptation to the TMR, followed by $6 \mathrm{wk}$ of experiment. The TMR were fed once daily at $1000 \mathrm{~h}$ ad libitum, allowing for 5 to $10 \%$ orts, and cows were milked 3 times daily at 0600, 1400, and $2200 \mathrm{~h}$. Cows were fed individually via a computerized monitoring system designed to electronically identify individual cows and to automatically control and record each cow daily feed intake (Miron et al., 2003). 
Daily DMI of individual cows was determined based on DM content in TMR sampled daily and feed refusals. Body weight was measured daily using an automatic walking balance located in the entrance to the milking parlor.

Milk yield ( $\mathrm{kg}$ ) was recorded daily for each cow by an automatic meter (AfiMilk; SAE Afikim, Kibbutz Afikim, Israel). Milk samples were collected in 3 sequential milkings on a weekly basis throughout the study. Milk samples were stored at $4^{\circ} \mathrm{C}$ in the presence of 2-bromo2-nitropropane-1,3-diol, until infrared analysis for fat, true protein, and lactose, using a MilkoScan 4000 apparatus (Foss Electric A/S, Hillerød, Denmark). Energy-corrected milk yield was calculated using the following equation (NRC, 2001): $\mathrm{ECM}(\mathrm{kg} / \mathrm{d})=$ milk yield $(\mathrm{kg} / \mathrm{d}) \times[(0.3887 \times$ milk fat \% $)+(0.2356 \times$ milk protein-urea \% $)+(0.1653 \times$ milk lactose $\%)] / 3.1338$ $\mathrm{MJ} / \mathrm{kg}$.

In the fifth week of the trial, TMR, feed refusals, and feces from 10 cows from each treatment were sampled for $6 \mathrm{~d}$. Samples of the TMR and refusals were composited by week, dried $\left(60^{\circ} \mathrm{C}\right.$ for $\left.48 \mathrm{~h}\right)$ and ground to pass a 1.0-mm sieve. Fecal grab samples were collected twice daily for $6 \mathrm{~d}$, at 12 -h intervals, each day $2 \mathrm{~h}$ later than the preceding day. Fecal samples were composited (on a DM basis) from each cow during the collection period, dried at $60^{\circ} \mathrm{C}$ for $48 \mathrm{~h}$ in an aerated oven, ground to pass through 1.0-mm screen, and then used for chemical and indigestible NDF analyses.

The 2-stage in vitro digestibility technique of Tilley and Terry (1963) was used to analyze the indigestible NDF content (after incubation with rumen fluid for 72 h) of TMR and feces samples, and in vivo digestibility was calculated according to Adin et al. (2008). The indigestible NDF was used as an internal marker for the apparent total-tract DM digestibility analysis. The in vivo digestibility of each chemical component (i.e., $\mathrm{DM}, \mathrm{CP}$, and NDF) was calculated in each cow using the average individual DMI and fecal output.

Once per week, 500-mL rumen fluid samples free of saliva were collected with a rumen vacuum sampler from 10 cows from each treatment, $1 \mathrm{~h}$ before feeding and $3 \mathrm{~h}$ after feeding. The rumen $\mathrm{pH}$ values were determined immediately by portable $\mathrm{pH}$ meter (M.R.C. Ltd., Holon, Israel). This cow performance and digestibility trial was carried out according to the guidelines, and under the supervision of the ARO Animal Care Committee.

\section{Chemical Composition and In Vitro Digestibility Analyses}

Samples of the W and CJ source material and silages, and of the 4 types of packed TMR before ensiling and after opening and during feeding to sheep or cows, as well as orts and fecal samples from the 2 animal experiments, were dried for $48 \mathrm{~h}$ in an aerated $60^{\circ} \mathrm{C}$ oven, ground to pass a 1-mm screen, and analyzed according to the methods of the Association of Official Analytical Chemists (AOAC, 1990) for DM (method 925.40), total N (method 984.13), ether extract (method 920.39), and ash (method 923.03) content. Crude protein was calculated as $\mathrm{N} \times 6.25$. Determination of NDF was as described by Van Soest et al. (1991) using heatstable amylase without sodium sulfite. The content of $\mathrm{ADF}, \mathrm{ADL}$, and residual ash were determined using the sequential method of Van Soest et al. (1991). An Ankom fiber analyzer (Ankom ${ }^{220}$; Ankom Technology, Macedon, NY) was used to extract and filter NDF and ADF. Hemicellulose was calculated as NDF - ADF, cellulose as ADF - ADL, and lignin as ADL - residual ash.

All forage samples and ensiled TMR were extracted in water ( $5 \mathrm{~g}$ of DM/100 $\mathrm{g}$ of water) and the extracts were used for direct $\mathrm{pH}$ and soluble nitrate content analyses. Soluble nitrate content in the water extracts was determined by a colorimetric method using a QuickChem 8000 system (Lachat Instruments, Milwaukee, WI). In vitro DM digestibility of the TMR was determined according to the 2-stage technique of Tilley and Terry (1963) using rumen fluid taken from the rumen of 2 cows equipped with a rumen fistula, fed TMR containing $300 \mathrm{~g}$ of CJ silage $+300 \mathrm{~g}$ of wheat silage $/ \mathrm{kg}$ of DM $+400 \mathrm{~g} / \mathrm{kg}$ of concentrate mixture.

\section{Statistical Analyses}

In experiment 1 , differences between the 4 types of TMR in Table 3 with respect to composition, in vitro digestibility, and changes occurring during ensilage, were based on analyses of bales ( $\mathrm{n}=4$ replicates) from each TMR type. Data was tested for significance by the F-test of ANOVA using JMP-5 software (SAS Institute, 1996). The Tukey test (SAS Institute, 1996) was used for comparison among means.

In experiment 2 , intake and in vivo digestibility by sheep were averaged by each of the 4 types of TMR fed $(\mathrm{n}=6$ sheep). Data (Table 4$)$ were analyzed as a randomized complete design using the F-test of ANOVA in JMP-5 software (SAS Institute, 1996). The Tukey test (SAS Institute, 1996) was used for comparison among means.

In experiment 3, feed intake, BW change, milk yield, milk composition, ECM yield, and milk components yields were averaged by cow for the $42 \mathrm{~d}$ of the experiment (42 repeated measures). Data were analyzed as a randomized complete block design using the mixed model of SAS software (SAS Institute, 1996). The sta- 
Table 4. Daily voluntary DMI and apparent digestibility of dietary components by sheep fed the 4 types of ensiled packed TMR

\begin{tabular}{lccccc}
\hline & \multicolumn{4}{c}{ TMR $^{1}$} \\
\cline { 2 - 4 } Parameter & W-S-TMR & CJ-S-TMR & W-TMR & CJ-TMR & SEM \\
\hline DMI (g/sheep) & $951^{\mathrm{b}}$ & $977^{\mathrm{ab}}$ & $886^{\mathrm{c}}$ & $1,003^{\mathrm{a}}$ & 8.98 \\
Digestibility (\%) & $70.5^{\mathrm{bc}}$ & $68.2^{\mathrm{c}}$ & $71.3^{\mathrm{ab}}$ & $73.1^{\mathrm{a}}$ & 0.61 \\
CP intake (g/sheep) & $166.6^{\mathrm{c}}$ & $178.3^{\mathrm{a}}$ & $170.6^{\mathrm{b}}$ & $181.6^{\mathrm{a}}$ & 1.25 \\
Digestibility (\%) & $71.7^{\mathrm{ab}}$ & $69.0^{\mathrm{b}}$ & $73.4^{\mathrm{a}}$ & $73.6^{\mathrm{a}}$ & 0.72 \\
NDF intake (g/sheep) & $350.9^{\mathrm{c}}$ & $364.0^{\mathrm{b}}$ & $358.7^{\mathrm{bc}}$ & $401.1^{\mathrm{a}}$ & 4.11 \\
Digestibility (\%) & $51.9^{\mathrm{b}}$ & $49.0^{\mathrm{b}}$ & $59.3^{\mathrm{a}}$ & $61.2^{\mathrm{a}}$ & 1.20 \\
\hline
\end{tabular}

${ }^{\mathrm{a}-\mathrm{c}}$ Means within a row with different superscripts differ at $P<0.05$.

${ }^{1} \mathrm{~W}-\mathrm{S}-\mathrm{TMR}=$ wheat $(\mathrm{W})$ silage + sorghum $(\mathrm{S})$ silage $(1: 2$ on a DM basis) as the roughage source; CJ-S-TMR $=$ Cephalaria joppensis $(\mathrm{CJ})$ silage $+\mathrm{S}$ silage (1:2 on a DM basis) as the roughage source; W-TMR $=340 \mathrm{~g}$ of fresh W DM/kg of DM; CJ-TMR = $340 \mathrm{~g}$ of fresh CJ DM/kg of DM as the roughage source.

tistical model included the effects of dietary treatment, block, and cow with block interaction. Cow within block was delineated as the random effect in the model and used to test treatment and blocks effects, whereas repeated measurements of daily data were tested for the residual error. Data are reported in Table 5 as condensed daily means for the $42 \mathrm{~d}$ of the experiment. The rumen $\mathrm{pH}$ and in vivo digestibility data (10 cow replicates for each dietary treatment) were analyzed for significance by the F-test of ANOVA using JMP-5 software (SAS Institute, 1996). The Tukey test (SAS Institute, 1996) was used for comparison among means.

\section{RESULTS AND DISCUSSION}

Recently, successful domestication of the wild ruderal species $C$. joppensis was done by U. Kushnir, and it was demonstrated that CJ can be grown as a high-yielding forage (Miron et al., 2010, 2011a). These preliminary observations motivated the present study aimed at measuring the potential of CJ silage to replace the commonly used $\mathrm{W}$ silage in lactating cow TMR. Unfortunately, there is a lack of data in the literature on the use of CJ as a forage crop grown intensively for feeding productive ruminants and, therefore, we were unable to compare the results obtained in this study with previous ones.

Domestication of a wild plant such as CJ for intensive growth as forage to be fed to milking dairy cows is a multistage process of research and development that includes (1) producing the minimal economically feasible forage mass per hectare; (2) producing adequate forage quality, as reflected by a minimum required extent of forage in vitro digestibility; (3) developing an adequate preservation system for the fresh forage, which is stored for several months before feeding; (4)

Table 5. Daily DMI, milk production and composition, and in vivo digestibility in lactating cows individually fed for 6 wk 2 types of packed TMR

\begin{tabular}{lccc}
\hline & \multicolumn{2}{c}{ TMR $^{1}$} \\
\cline { 2 - 3 } Parameter & W-S-TMR & CJ-S-TMR & SEM \\
\hline Number of cows & 21 & 21 & \\
Milk yield (kg/cow) & $36.5^{\mathrm{a}}$ & $35.5^{\mathrm{b}}$ & 0.18 \\
Milk fat (\%) & 3.21 & 3.21 & 0.05 \\
Milk protein (\%) & 2.78 & 2.74 & 0.03 \\
Milk lactose (\%) & 4.79 & 4.78 & 0.01 \\
ECM yield (kg/cow) & $31.4^{\mathrm{a}}$ & $30.4^{\mathrm{b}}$ & 0.20 \\
BW change (kg) & 7.81 & 6.65 & 0.50 \\
Rumen pH & 6.96 & 6.91 & 0.10 \\
DM intake (kg/cow) & 22.0 & 21.6 & 0.31 \\
DM digestibility (\%) & 69.0 & 68.2 & 0.40 \\
CP digestibility (\%) & 66.1 & 68.0 & 0.50 \\
NDF digestibility (\%) & $55.0^{\mathrm{a}}$ & $51.2^{\mathrm{b}}$ & 0.68 \\
Cellulose digestibility (\%) & $57.1^{\mathrm{a}}$ & $54.3^{\mathrm{b}}$ & 0.67 \\
Hemicellulose digestibility (\%) & 56.2 & 56.1 & 0.37 \\
\hline
\end{tabular}

$\overline{\mathrm{a}, \mathrm{b}}$ Mean values in the same row followed by different superscripts differ at $P<0.05$.

${ }^{1} \mathrm{~W}-\mathrm{S}-\mathrm{TMR}=\mathrm{TMR}$ ensiled in packed bales, containing $114 \mathrm{~g}$ of wheat silage $\mathrm{DM} / \mathrm{kg}$ of $\mathrm{DM}+226 \mathrm{~g}$ of sorghum silage DM/kg of DM as roughage source; CJ-S-TMR = TMR ensiled in packed bales, containing 114 $\mathrm{g}$ of Cephalaria joppensis silage DM/ $\mathrm{kg}$ of DM $+226 \mathrm{~g}$ of sorghum silage DM/kg of DM as roughage source. 
producing plant varieties that are highly palatable to sheep, due to their highly sensitive feed-selection capability among ruminants; and (5) measuring utilization of the new plant variety by lactating cows for milk and ECM production.

Forage production of at least $5 \mathrm{t}$ of forage $\mathrm{DM} / \mathrm{ha}$ is the minimal level justifying the agrotechnical expenses invested in field preparation, sowing, fertilization, herbicide application, and harvesting (Van Soest, 1994). Table 1 shows that, based on measurements in 5 subplots, CJ harvested at the beginning of the bloom yielded $16.4 \mathrm{t}$ of forage DM/ha, which was $37 \%$ higher than that of neighboring grown $\mathrm{W}$ forage. Wheat yield data obtained in this study is comparable to data of previous observations (Duncan et al., 2011; Miron et al., 2011b; Zuckerman et al., 2011). The yield of CJ (Table 1) is about $105 \%$ greater than the yield of winter vetch or clover hay (DePeters et al., 1989; Shteinberg et al. 2003).

According to the literature, low-quality forage with in vitro digestibility below $55 \%$ interferes with voluntary ingestion and might decrease milk production in lactating dairy cows (Van Soest, 1994). The present study showed that the in vitro DM digestibility of fresh CJ was $62 \%$, similar to that of commercial $\mathrm{W}$ forage (64\%; Table 1). The CJ plants contained lower NDF, hemicellulose, and soluble nitrate concentrations and higher cellulose and lignin concentrations compared with W.

Development of a preservation system that can adequately preserve the freshly harvested forage for several months until feeding is essential for any new forage used in TMR for lactating cows. The methods commonly used for fresh forage preservation are direct ensilage, ensilage after a prewilting stage or additive supplementation, and complete wilting in the field for hay production. Forages that are difficult to ensilage directly at harvest because of high moisture content or high buffer capacity such as sorghum, ryegrass, or alfalfa require a highly costly prewilting stage or supplementation of ensiling additives (Ben-Ghedalia et al., 1993; Miron and Ben-Ghedalia, 1994; Weinberg et al., 2007) to produce a good silage.

The effects of ensiling for $30 \mathrm{~d}$ fresh-cut CJ versus fresh-cut wheat in packed bales on their composition and in vitro digestibility is shown in Table 1. Ensiling of fresh-cut $\mathrm{W}$ and CJ resulted in $\mathrm{pH}$ reduction from 6.1 to 4.42 and 4.56, respectively, and the reduction of soluble nitrate content in both forages. Losses of $\mathrm{DM}$ during ensilage, content of NDF and CP, and in vitro digestibility of the 2 types of silages were low and similar. Silage contamination by yeasts and molds was minimal in both silages.
The effects of direct inclusion of fresh CJ versus fresh $\mathrm{W}$ as sole roughage source in packed TMR on composition, nutrient loss during ensilage, and aerobic stability of the ensiled TMR are given in Table 3. This table also provides the effects of inclusion of CJ silage versus W silage combined (in a 1:2 ratio on a DM basis) with $\mathrm{S}$ silage into packed TMR on TMR composition, nutrient loss during TMR ensilage, and aerobic stability of the ensiled TMR. For the 4 types of TMR containing chopped wet forage or silage mixed with wet TMR components (Table 2), the packing and wrapping created anaerobic conditions and ensilage occurred within the packed TMR bales. This ensilage process resulted in a significant reduction in TMR $\mathrm{pH}$ from 4.7 in TMR containing silages and 6.0 in TMR containing fresh forages to $\mathrm{pH} 4.1$ and 4.3 , respectively. The DM loss within the bales during ensilage was higher for TMR containing W compared with CJ.

In the 4 types of TMR, the ensiling process resulted in a reduction of soluble nitrate content and of yeast and mold contamination. Ensiling also resulted in greater NDF solubilization within the W-TMR compared with the CJ-TMR and the TMR-containing silages. However, $\mathrm{NDF}$ and $\mathrm{CP}$ contents, as well as in vitro DM digestibility, were similar in the 4 types of ensiled TMR. The 4 TMR types were also characterized by great aerobic stability during $7 \mathrm{~d}$ of exposure to air, as reflected by low $\mathrm{CO}_{2}$ production, preservation of low $\mathrm{pH}$ (Table 3 ), and lack of contamination by yeasts and molds (data not shown).

It should be noted that CJ is characterized by a longer and slower period of plant maturation compared with $\mathrm{W}$. In $\mathrm{W}$, within a short period of 3 wk the plants advance from the beginning of the flowering stage to the soft-dough stage of grain maturation, which is the optimal stage for silage harvesting (Ben-Ghedalia et al., 1995). In CJ, maturation from the beginning of flowering to the beginning of seed development occurs within 2 to 4 mo while preserving the high yield and digestibility values of the CJ plants during this period (Miron et al., 2010). These characteristic enable continuous production for at least 2 to 4 mo of freshly harvested CJ used for direct inclusion in packed ensiled TMR bales. This system enables skipping the preensilage stage immediately after harvest, which saves cost, minimizes nutrient losses during extra ensiling, and produces highly digestible ensiled TMR characterized by low $\mathrm{pH}$, long shelf life under outdoor conditions, high aerobic stability after opening for feeding, and minimal contamination by yeasts and molds (Table 3 ). Advantages of this ensiled packed TMR bale preparation system for lowering transportation cost to far-away places were previously described by Weinberg et al. (2011). 
It is well recognized in the literature that sheep are more sensitive than dairy cows to the taste, smell, structure and quality of feeds and accordingly are more selective in TMR feeding (Van Soest, 1994). Therefore, new feeds included in TMR that are willingly ingested and digested by sheep will probably also be palatable to lactating cows. The sheep trial of this study measured the voluntary intake and digestibility of dietary components by 6 sheep (replicates) fed each of the 4 types of ensiled packed TMR, and the results are shown in Tables 2 and 3. Data in Table 4 show greater voluntary intake by sheep fed the CJ-TMR compared with the 2 TMR containing W. This higher intake of CJ-TMR might be associated with its higher digestibility of DM, CP, and NDF compared with the CJ-S-TMR and W-STMR that contained preensiled forages. This advantage of CJ-TMR cannot be explained by lower digestibility of $\mathrm{S}$ silage because the in vitro DM digestibility of the S silage was similar to that of CJ silage $(61 \%)$. A possible explanation of this finding might be related to the advantage of the direct CJ-TMR preparation system that avoid nutrients and soluble carbohydrate losses occurring during the extra preensiling stage before CJS-TMR preparation (Tables 1 and 3).

Finally, any new forage species should be examined for its nutritive value when included in a TMR fed to lactating cows relative to commonly used forage. The cow trial (Table 5) examined the intake, digestibility, milk production, and composition and BW change in lactating cows individually fed the ensiled packed CJS-TMR compared with W-S-TMR. The 21 cows fed the W-S-TMR were characterized by similar voluntary DMI and similar digestibility of DM and $\mathrm{CP}$ as cows fed the CJ-S-TMR. However, NDF and cellulose digestibility were greater in cows fed the W-S-TMR compared with the group fed CJ-S-TMR, and this was reflected in 2.8 and $3.3 \%$ greater milk and ECM yields, respectively, for the former (Table 5).

In this study, sheep and cows were fed the same TMR, containing $34 \%$ forage as commonly used in Israeli dairy herds. Values of DM and CP digestibility of CJ-S-TMR and W-S-TMR were similar in sheep fed for ad libitum intake at maintenance level compared with lactating cows fed 3 times maintenance level. However, NDF digestibility was lower in cows compared with sheep, probably due to the faster rate of passage of forage NDF from the rumen, as described previously (Van Soest 1994; Adin et al. 2008).

An additional advantage of growing CJ is that because it belongs to the class dicotyledon, CJ can be integrated in multi-seasonal growth cycles in rotation with monocotyledonous forages, particularly cold-season $\mathrm{W}$ and summer-grown corn and S. This improves the efficiency of land, herbicide, and water use in a multi-seasonal forage production system, because the forage yield of CJ is about $105 \%$ greater than that of vetch or clover hay (DePeters et al., 1989; Shteinberg et al. 2003) commonly used in Israel for multi-seasonal rotation with monocotyledonous forages.

\section{CONCLUSIONS}

The present study provides a novel method of using crops of the wild plant $C$. joppensis as a forage for ruminants. The results demonstrate that freshly harvested CJ used as is, or CJ-based silage packed in polyethylene bales can be included in a TMR for productive ruminants as high-quality forage, with a nutritive value for sheep and dairy cows similar to that of $\mathrm{W}$ silage. Hence, CJ silage can replace commercial W silages as feed for lactating dairy cows. The present study also shows that while ensiled in polyethylene-packed bales, the TMR containing CJ and CJ silages are characterized by a long outdoor shelf life of at least 3 mo and high stability under aerobic exposure. According to the present study, CJ is also characterized by high DM digestibility (59 to $61 \%$ ) and low content of nitrates $(<2.5 \mathrm{~g} / \mathrm{kg}$ of DM).

\section{ACKNOWLEDGMENTS}

This study was supported by grants from the Chief Scientist of the Israeli Ministry of Industry and Trade (Jerusalem, Israel) and from the Israeli Dairy Board, Yehud, Israel.

\section{REFERENCES}

Adin, G., R. Solomon, E. Shoshani, I. Flamenbaum, M. Nikbachat, E. Yosef, A. Zenou, I. Halachmi, A. Shamay, A. Brosh, S. J. Mabjeesh, and J. Miron. 2008. Heat production, eating behavior and milk yield of lactating cows fed two rations differing in roughage content and digestibility under heat load conditions. Livest. Sci. 19:145-153.

AOAC (Association of Official Analytical Chemists). 1990. Official Methods of Analysis. Vol. 1. 15th ed. AOAC, Washington, DC.

Atlas of Israeli Flowers. 2010. Cephalaria joppensis. Accessed Jan. 2, 2012. http://www.flowersinisrael.com/Cephalariajoppensis_page. htm.

Ben-Ghedalia, D., A. Kabala, and J. Miron. 1995. Composition and in-vitro digestibility of carbohydrates of wheat plants harvested at bloom and soft-dough stages. J. Sci. Food Agric. 68:111-116.

Ben-Ghedalia, D., E. Yosef, and J. Miron. 1993. Pectin fermentation and utilization by natural microflora during ryegrass ensilage. Anim. Feed Sci. Technol. 41:113-119.

DePeters, E. J., J. F. Medrano, and D. L. Bath. 1989. A nutritional evaluation of mixed winter cereals with vetch utilized as silage or hay. J. Dairy Sci. 72:3247-3254.

Duncan, R., D. Hathcoat, T. Baughman, B. Bean, D. Drake, C. Jones, T. Miller, C. Trostle, J. Swart, A. Ibrahim, J. Rudd, R. Devkota, J. Baker, R. Herrington, B. Simoneaux, J. Simmons, R. Sutton, D. Worrall, R. Borchardt, M. Schoppa, and R. Padilla. 2011. Texas Wheat Variety Trial Results. Special publication of Texas AgriLife Extension Service and Texas AgriLife Research. Accessed Jan. 2, 
2012. http://varietytesting.tamu.edu/wheat/docs/2011/2011\%20 Wheat.pdf

Miron, J., and D. Ben-Ghedalia. 1994. Monosaccharide digestibility by dairy cows fed diets high in concentrated and containing alfalfa silages. J. Dairy Sci. 77:3624-3630.

Miron, J., I. Raviv, A. Bloch, Y. Porat, B. Keinan, E. Yosef, M. Nikbachat, A. Zenou, G. Adin, Y. Portnik, S. Yakobi, I. Mizrahi, and U. Kushnir. 2011a. Cephalaria as a replacement of wheat silage or hay-Influence on the milk yield and composition. In Proc. 23rd Annual Meeting of Cattle Sciences, Jerusalem, Israel. Israeli Extension Service, Ministry of Agriculture, Bet Dagan, Israel.

Miron, J., I. Raviv, Z. G. Weinberg, A. Bloch, Y. Porat, E. Nahim, D. Miron, E. Yosef, M. Nikbachat, A. Zenou, G. Adin, Y. Portnik, S. Yakobi, Y. Chen, C. Nashaf, and U. Kushnir. 2010. Cephalaria-A new forage plant. Meshek Habakar Vehachalav 346:70-72.

Miron, J., E. Yosef, E. Maltz, and I. Halachmi. 2003. Soybean hulls as a replacement of forage NDF in TMR of lactating cows. Anim. Feed Sci. Technol. 106:21-28.

Miron, J., E. Yosef, M. Nikbachat, A. Zenou, E. Zuckerman, R. Solomon, and A. Nadler. 2011b. Fresh dairy manure as a substitute for chemical fertilization in growing wheat forage; effects on soil properties, forage yield and composition, weed contamination, and hay intake and digestibility by sheep. Anim. Feed Sci. Technol. 168:179-187.

NRC. 2001. Nutrient Requirements of Dairy Cattle. 7th ed. National Academy Press, Washington, DC.

SAS Institute. 1996. SAS/STAT Software Changes and Enhancements. SAS Institute Inc., Cary, NC.
Shteinberg, Y., U. Levi, A. Izenkut, Y. Bernstein, D. Sade, and E. Zuckerman. 2003. Survey of legume cultivars and their combinations in Izrael Velley. Pages 41-44 in Summary of Forage Field Experiments, 2003. Special publication of The Israeli Extension Service, Ministry of Agriculture, Bet Dagan, Israel.

Tilley, J. M., and R. M. Terry. 1963. A two-stage technique for the in vitro digestion of forage crops. J. Br. Grassl. Soc. 18:104-111.

Van Soest, P. J. 1994. Function of the ruminant forestomach (pages 236-243) and Intake (pages 337-343) in Nutritional Ecology of the Ruminant. Cornell University Press, Ithaca, NY.

Van Soest, P. J., J. B. Robertson, and B. A. Lewis. 1991. Methods for dietary fiber, neutral detergent fiber, and nonstarch polysaccharides in relation to animal nutrition. J. Dairy Sci. 74:3583-3597.

Weinberg, Z. G., Y. Chen, D. Miron, I. Raviv, E. Nahim, A. Bloch E. Yosef, M. Nikbahat, and J. Miron. 2011. Preservation of total mixed rations for dairy cows in bales wrapped with polyethylene stretch film-A commercial scale experiment. Anim. Feed Sci. Technol. 164:125-129.

Weinberg, Z. G., O. Shatz, Y. Chen, E. Yosef, M. Nikbahat, D. BenGhedalia, and J. Miron. 2007. Effects of lactic acid bacteria inoculants on in vitro digestibility of wheat and corn silages. J. Dairy Sci. 90:4754-4762.

Zuckerman, E., U. Nir, B. Noy, O. Rabinovic, O. Goren, Y. Giladi, and A. Bosak. 2011. National examinations of wheat varieties for forage - Season 2010/11. Special publication 870-1564-11. The Ministry of Agriculture, Bet Dagan, Israel. 